\title{
The Effect of Circuit Training Method on Improving Physical Condition
}

\author{
Edwarsyah $^{1^{*}}$, S Hardiansyah ${ }^{1}$ \\ ${ }^{1}$ Faculty of Sports Science, Universitas Negeri Padang, Prof. Dr. Hamka Street, Padang, Indonesia \\ *Corresponding author. Email: edwarsyah@fik.unp.ac.id
}

\begin{abstract}
The issue of this study is that many students of Sports Science Faculty do not maximized their capability of physical condition. The aim of this study is to determine the effect of circuit training methods on improving physical conditions. This quasi-experimental research involved 9 students. The data were collected through 50 meter run test, sip up test, push up test and multi stage test. Data were analyzed using different test formula $(\mathrm{t}$ test) dependent samples. Based on the measurement and analysis, it was obtained that tcount $=3.03$ while ttable $=1.860$ at $\alpha 0.05$ and $\mathrm{df}=\mathrm{n}-1$. Thus, it can be concluded that the circuit training method has a significant effect on improving the ability of physical conditions. The circuit training is recommended to be used to improve physical condition.
\end{abstract}

\section{Keywords: Circuit training method, physical condition}

\section{INTRODUCTION}

Physical condition is the main need of every human being, from athletes, students to the general public. However, the demands of physical condition for each person vary depending on the daily activities. Student is one part that requires excellent physical condition, given a large number of activities carried out both on campus and off campus, therefore the objective of this study was to improve the ability of the physical condition through circuit training methods.

\section{Physical condition}

Pasurnay (2001) argued that physical condition is all physical abilitiy that determines achievement, while Sajoto (1988), Ihsan (2014) said that physical conditions are the basis of the starting point of the sport. From the two opinions above, it can be interpreted that physical condition is a physical ability which is the main requirement for achievement in the field of sport, but basically, physical condition is not only needed by sportsmen but also in the general public to be able to carry out all daily activities. There are several elements that including of physical conditions, namely: According to Hardiansyah (2017) strength is the ability of muscles to accept a burden, something similar to that

\section{Strength}

Delivered by Edwarsyah et al (2017) strength is the ability of a group of muscles to hold the burden when carrying out an activity. Based on the opinions, it can be described that strength is the ability of muscles to accept the burden of a physical activity.

\section{Speed}

Arsil (2009), Ihsan (2018) argues that speed is the body's ability to resist load, distance and time that produces mechanical work. Ismaryati (2008), Nurul (2018) says that speed is the ability to move with the best possible speed. So, it can be said speed is the body's ability to resist the load until it can move with long distances and a short time.

\section{The Explosion of Leg Muscles}

Explosive power is the multiplication of power and speed. According to Hardiansyah (2017), explosive power is the ability of a muscle to overcome a load at high speed in a whole movement. According to Edwarsyah et al (2017) explosive power is the ability to deal with presonal power quickly. From some of these opinions, it can be interpreted that the explosive power of the leg muscles is the ability of the leg muscles to produce movements quickly and strongly.

\section{Endurance}

Endurance is the ability of muscles or a group of muscles to anticipate fatigue caused by loading in a relatively long period of time. According to Arsil (2009) "endurance is defined as the length of time a person can do work intensity or far from exhaustion".

\section{Circuit Training Method}

According to Halil (2009), the circuit training method is an exercise that combines many forms of training sequentially with a very short rest period, whereas according to Hardiansyah (2017) the circuit training method is an exercise consisting of various 
forms of training variations which are divided into several posts so that the exercise be effective and efficient. Edwarsyah et al (2017) argues that the circuit method is an exercise consisting of many forms of exercises that combine elements of physical conditions.

From some opinions above, it can be interpreted that the method of circuit training is a combined training method of several elements of physical conditions into a series of exercises using several posts or stations with the aim of improving physical conditions. The element of physical condition that is the focus of this research consists of speed, strength, explosive power and endurance.Therefore the material in the posts is designed according to the training material that can increase the four elements of the physical condition. The intensity of the training starts from the moderate level to the maximum level.

The circuit training method has several advantages including (1) varied training so it is not boring. (2) training does not require a large area. (3) the muscles do not experience excessive fatigue because the training material at each post is different, (4) It can train various types of muscles in a set of exercises. Besides has several advantages of the circuit training method, it also has several disadvantages including: (1) it is difficult to exercise good control because of the many posts. (2) it is difficult to measure and adjust the load optimally at each post.

\section{METHOD}

This type of research was quasi-experimental using the circuit training method for 16 meetings. In the sample, there were 9 students from three majors namely Sports Science, Sports Education, and Sports Training. The instrument that becomes a measuring instrument is using a 40 meter run-test to measure speed, a push-up test to measure arm muscle strength, sit-up tests to measure abdominal muscle strength, standing broadjump test to measure the explosive pow er of leg muscles and multi-stage tests to measure endurance ability. The obtaineddata is processed using a different test analysis (t) sample dependent by comparing the beginning ability with the final ability (after treatment).

\section{RESULT AND DISCUSSION}

\section{Result}

Based on the results of measurements that made on a sample of 9 students at the beginning and end of the treatment, the results obtained were as follows:

\section{Pre test}

Based on the analysis carried out obtained the highest score of 58.12, the lowest score of 36.28. Based on the data group, the physical condition is obtained by the average value of calculation (mean) 51.13, the middle value (median) 51.04, and the standard deviation (standard deviation) of 6.84. For more details, the distribution of physical condition data can be seen in table 1 .

Based on the calculations listed in table 1 , it can be seen that there were no students $(0.00 \%)$ who had the physical condition in a very good category, and 4 people $(44.44 \%)$ had good physical condition, 3 people $(33.33 \%)$ had the physical ability in the medium category, and 1 person $(11.11 \%)$ had the ability of the physical condition in the less category and 1 student $(11.11 \%)$ who had the ability of the physical condition in the very less category. Frequency distribution of the ability of physical conditions can also be seen in figure 1:

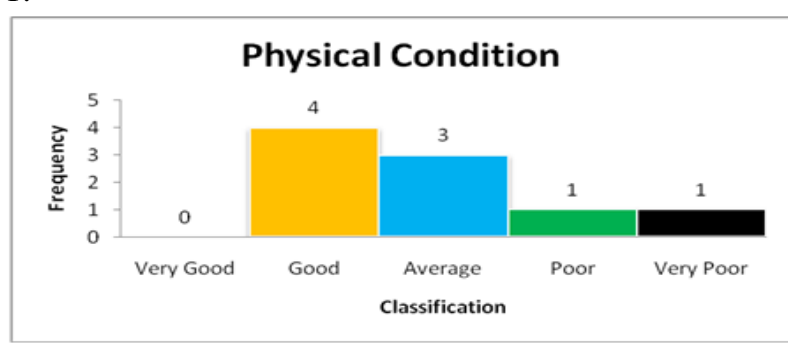

Figure 1. Histogram Ability of Physical Condition (Pre-Test).

\section{Post-test}

From the results of measurement the final physical condition data (speed, arm muscle strength, abdominal muscle strength, leg muscle explosive power and endurance) wereobtained the highest score that was 62.80 and the lowest score was44.96. Based on the physical condition data group, the calculated average value (mean) was 56.48, the middle value (median) was 58.81 , and the standard deviation is 6.27 . For more details, the distribution of physical condition data can be seen in table 2 .

Based on the calculations listed in table 2, it can be seen that 3 students $(33.33 \%)$ had excellent physical abilities, and 3 students (33.33\%) had physical abilities in good categories, 2 persons $(22.22 \%)$ had conditions physical in the medium category, and 1 person $(11.11 \%)$ has the ability of the physical condition in the less category and no student $(0.00 \%)$ has the ability to physically condition the very category less. Frequency distribution of the ability of physical conditions can also be seen in figure 2 


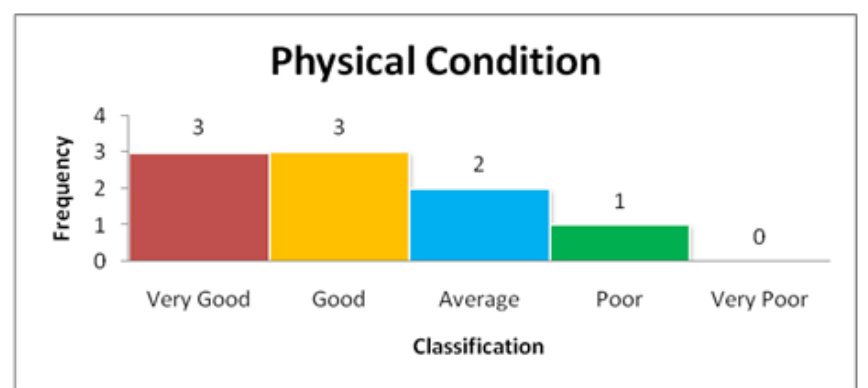

Figure 2. Histogram Ability of Physical Condition (Post Test).

Testing Requirements for Analysis (Normality Test)

Before testing the hypothesis, the first step was to test the requirements analysis to ensure the research data comes from populations that are normally distributed using the liliefors test. Based on the normality test performedwere obtained $\mathrm{L}_{\text {observation }}$ on the pre test data was 0.1535 and $\mathrm{L}_{\text {observation }}$ in the post test data was 0,1569 , while value of $\mathrm{L}_{\text {table }} \mathrm{On} \alpha=0.05$ and $\mathrm{n}=$ 9 was 0.27 , thus the value of $\mathrm{L}_{\text {observation }}<\mathrm{L}_{\text {table. }}$ So, it can be concluded that the data comes from normally distributed populations. The results of normality testing can be seen in table 1 .

Tabel 1. Results of Normality test.

\begin{tabular}{|l|c|c|c|}
\hline Group & $\mathrm{L}_{0}$ & L-table & Information \\
\hline Pre-test & 0.1535 & 0.27 & Normal \\
\hline Post-test & 0.1569 & 0.27 & Normal \\
\hline
\end{tabular}

Hypothesis Testing

The hypothesis proposed in this study that there is a method of circuit training that had a significant influence on improving physical abilities. Based on the calculations that had been done on the pre-test data, it was obtained an average of 51.13 and the average posttest was 56.48 after the data analysis using the dependent sample t-test, then obtained value of $t_{\text {count }}$ of 3.03 and $t_{\text {table }}$ obtained from value $\alpha=0.05$, df $=n-1$ of 1.860 , thus value of $t_{\text {test }}(3.03)>t_{\text {table }}(1.860)$. It can be concluded that $\mathrm{H}_{0}$ is rejected and $\mathrm{H}_{1}$ is accepted.In other words, hypothesis proposed in this study can be accepted as empirically. The results of hypothesis testing can be seen in table 4 .

Table 2. Results of Hypothesis Testing.

\begin{tabular}{|l|l|l|l|l|l|}
\hline Group & Mean & $\mathrm{t}_{\mathrm{c}}$ & $\mathrm{df}$ & $\mathrm{t}_{\mathrm{t}}$ & Information \\
\hline $\begin{array}{l}\text { Pre- } \\
\text { test }\end{array}$ & 50.00 & \multirow{2}{*}{3.03} & $\mathrm{n}-1$ & 1.860 & $\begin{array}{l}\text { Significantly } \\
\text { different }\end{array}$ \\
\hline $\begin{array}{l}\text { Post- } \\
\text { test }\end{array}$ & 55.67 & & & & \\
\hline
\end{tabular}

\section{Discussion}

Based on the results of measurements that had been made on the elements of the physical condition that are the focusing in this study namely, the speed, strength, explosion of leg muscles and endurance at the beginning and final of the exercise along data analysis using the t-test to see the difference between pre-test data and post-test, it were obtained informations that the hypothesis in this study was accepted with the meaning that the circuit training method had a significant influence on improving the physical condition the students of the Faculty of Sport Sciences, it is according to opinion Sebic (2016) that circuit training can be increasing muscle stamina and endurance.

The method of circuit training differs from other training methods that are used to improve the ability of physical conditions. According to Halil (2009), the circuit training method had the characteristic that this exercise had posted, if the exercise in one post had been completed then it must move to another post.

In accordance with the principles of circuit training, the exercises were designed for 6 posts and the training material in each post was different from the other posts. A movement that aimed to train the same muscle is not given to the adjacent post with the aim that the muscles do not experience excessive fatigue. The exercise was carried out continuously for several weeks by adjusting the dosage between good work and rest so, as to provide an increase in the physical condition of the students who were sampled in this study. This is in accordance with Jill argue (2017) that circuit training methods can improve muscle fitness through exercises carried out several weeks with proper work-rest settings.

In addition to good work and rest settings, setting the intensity can also affect the impact given by circuit training, because if the exercise is not carried out with maximum intensity then the effects provided by the circuit training will also not be optimal. According to Ambrozy (2017) high-intensity circuit training will affect various components of the physical condition, therefore setting the intensity in this study starts from moderate to high intensity. The magnitude of the effects of the training given to improving physical conditions can be influenced by nutritional intake and resting time, but based on the results of the research described above, the training circuit method is highly recommended for use in an effort to improve physical condition because it is in Jill's opinion (2017) the circuit training method is a practical and efficient exercise. From this opinion, this exercise tends to be more efficiently on time period and practical in terms of implementation. 


\section{CONCLUSION}

Based on the results of research, it can be concluded thatthe circuit training method has a significant influence on improving physical condition.

\section{REFERENCES}

[1] Ambrozy, Tadeusz. 2017. Influence of experimental training with external resistance in a form of "kettbell" on selected components of women's physical fitness. Baltic Journal of Health and Physical Activity. Volume 9 (1) 2017: 28-36

[2] Arsil. (1999). Pembinaan Kondisi Fisik. Padang: Sukabina.

[3] Arsil.(2009). Tes Pengukuran Dan Evaluasi Pendidikan Jasmani Dan Olahraga. Padang : FIK UNP.

[4] Edwarsyah, Hardiansyah Sefri, Syampurma Hilmainur. (2017). Pengaruh Latihan Sirkuit Training Terhadap Kondisi Fisik Atlet Pencak Silat Unit Kegiatan Olahraga Universitas Negeri Padang. Jurnal: Penjakora. Vol. 4 No 1: 51-63.

[5] Halil Taskin. 2009. Effect Of Circuit Training on The Sprint-Agility and Anaerobic Endurance. Journal of Strength and Conditioning Research, Volume 23 No 6, 1803-1810.

[6] Hardiansyah Sefri. 2017. The Influence Of Circuit Training Method On The Enhancement Of Physical Fitness Of Sports Education Department Students. Proceedings The $1^{\text {st }}$ Yogyakarta international seminar on health, physical education, and sports science: Yogyakarta.

[7] Ihsan. N. 2014. The analysis of the physical condition, will pencak silat construction training center students (PPLP) of West Sumatra. International Seminar of Sport Culture and Achievement

[8] Ismaryati. (2008). Tes dan Pengukuran Olahraga. Surakarta: UNS Press.

[9] Jill Maples. 2017. A Comparison of High Intensity Functional Training and Circuit Training on Health and Performance Variables in Women: A Pilot Study. Journal Women in Sport and Physical Activity, Volume 25 2017, 1-10.

[10] Nurul Ihsan, dkk. 2018. Instrumen Kecepatan Tendangan Pencak Silat Berbasis Teknologi. Jurnal Sosioteknologi 17 (1), 124-131

[11] Nurul Ihsan, Suwirman. 2018. Sumbangan Konsentrasi terhadap Kecepatan Tendangan Pencak Silat. Jurnal Media Ilmu Keolahragaan Indonesia 8 (1)

[12] Pasurnay Paulus Levinus, 2001. Latihan Fisik Olahraga. Pusat Pendidikan dan Penataran KONI Pusat: Yogyakarta.

[13] Sajoto, Muchammad. (1988). Pembinaan Kondisi Fisik dan Olahraga. Jakarta: Depdikbud
[14] Sebic Lejla. 2016. Effects of circuit training on Body composition of women. Journal Homo Sporticus Issue 2 2016, 28-34. 